\title{
Jobofifetime
}

\section{Discovering today's van Goghs: Sandra Kroupa and the Book Arts Collection at the University of Washington}

$\mathbf{T}_{\mathrm{o}}^{\mathrm{h}}$ he Book Arts Collection at the University of Washington Library is a regional treasure. With more than 14,000 pieces representing the range of bookmaking techniques, students and scholars alike have access to beautiful limited edition artists' books. The woman responsible for this collection is Sandra Kroupa, book arts and rare book curator. Entering her 40th year in the University of Washington's Special Collections Division, Kroupa truly has had a job of a lifetime.

\section{How it all started}

Kroupa's career began with what she believed would be a short-term job. "I was in the creative writing program here at University of Washington. I was 21, and I needed to make some money. I got a job in Special Collections reading newspapers and turning the facts into $3 \times 5$ cards on a manual typewriter. I thought I was only going to be

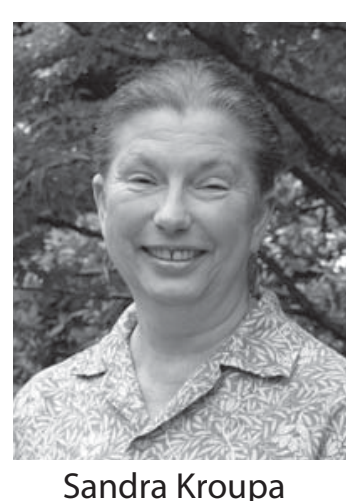

Sandra Kroupa along the line I said we really should be looking at more experimental work. It's kind of like buying someone like Renoir when he was a working artist as opposed to waiting 25 or 50 years and then buying one. How many van Goghs would there be if somebody had actually been supporting him at the time?"

\section{What makes a book a book?}

Kroupa doesn't try to answer that question. "I don't define the word book. I might have known what that was years and years ago, but I have no idea now. Artists are constantly reinterpreting it. My job is to provide a collection that gives multiple definitions to the word book. Hopefully, people leave the collection with a broadened view of what a book is." There's plenty to stretch the viewer's conception of a book. "We collect sculptural work, things that don't open, things that are glued together, things that have nails driven through them. The whole idea is the book as a symbolic object."

\section{Conduit for the artist}

Connecting students with the collection is one of Kroupa's favorite parts of her job. "My job is primarily to be the conduit between the artist and viewer. The artist can't talk to the person directly, but they can talk to them through me as I provide the book." For this reason, Kroupa prefers to buy directly from

Ann Wheeler is the librarian at the Maryland Department of Natural Resources. Have a story idea for Job of a Lifetime? E-mail Ann at awheeler@dnr.state.md.us 
artists rather than through dealers. "I like to talk to the artist about the book, about the methodology and techniques. Usually I try not to ask what the book is about, because in general artists don't like to be approached that way, so I'll ask about the printmaking technique or the structure. Invariably after a few minutes they're telling me what the book is about without me asking. Those are the stories that I can communicate to the student to help them understand more richly what they are viewing."

Kroupa often makes this connection through teaching. She describes a typical class scenario, such as an English class exploring the concept of autobiography. "I'll get out 100 or 150 pieces. About half of them are things I'll put on the tables for students to pay attention to or not, and half of them are things I'll talk about. Invariably, in that kind of environment, there will be two or three students that pick up a book that really speaks to them, and go over in a corner and sit down with it and actually read it cover to cover. Many times people are in tears. I don't go anywhere where I don't carry a box of Kleenex with me."

This type of strong reaction doesn't sur-

\section{Book Arts and Rare Books curator} What: Book Arts Collection Where: University of Washington

For more information, visit: http://www.lib.washington.edu /specialcol light bulb going off in their head. I can't do that if I only represent my own aesthetic or my own point of view." Kroupa's attention to collecting outside her own aesthetic definitely benefits the students. "An artist once sent me something that was very technically good, but the imagery just didn't speak to me at all. I bought it anyway, and sure enough, the first time I used it in a class a young woman clutched this book to her chest and said, 'I love this!"”

\section{Role of the subject specialist}

Kroupa believes that librarians have an important role to play as subject specialists, not just as experts at finding information. "When I first started in the field, the idea of specializing in something was highly regarded. Now it appears we're kind of 180 degrees away from that. One of the things librarians can do is take a specific object and put it in a larger context, but in order to do that you actually have to know something about it.

I would encourage people who are early in their career to find some part of what they do that they want to concentrate on, and really get good at it."

Although there aren't a lot of job prise Kroupa. "What artists are doing in books is creating an intimate environment in which they're usually talking about something that matters to them a lot. Often if it's something that speaks to you at all, it hits you in the chest with some kind of ferocity. When that happens, that's the whole point of this."

Although artists' books often affect viewers on an emotional level, Kroupa doesn't name favorites. "I do not buy things that I 'like.' I buy things that fit with the collection. I never share what I like or don't like. For me, once a book comes into the collection, my job is to be its advocate, no matter how I feel personally about it. I need to find a book that will get every student who comes here some emotional attachment or some openings in special collections, Kroupa hopes to see that change. "I'm seeing the theme at a lot of conferences that special collections are the future of the library profession, because we have unique materials that people will come across the county to see. I hope I live to see that happen with sufficient support and staffing behind it."

But if Kroupa's job sounds like your dream job, you may have to wait. "My plan is to never retire, just to die at my desk. I'm of the generation where I'm kind of flabbergasted they pay me to do this. It sounds schmaltzy, but pretty much every day I walk into this building I feel proud that I'm able to contribute to this place." In her amazing career, Kroupa has contributed a lot. $\boldsymbol{z}$ 